(C) 2013

Окселенко Н. О., асистент

Дніпропетровський державний аграрний університет

\title{
ОСОБЛИВОСТІ ЗАСТОСУВАННЯ МОДЕЛЕЙ ЛОНГІТЮДНИХ ДАНИХ ДЛЯ СІЛЬСЬКОГОСПОДАРСЬКИХ ПІДПРИЕМСТВ
}

\author{
Рецензент - доктор економічних наук, професор Л. Ю. Мельник
}

\begin{abstract}
Робота розкриває питання вдосконалення процесу управління оборотними активами сільськогосподарських підприсмств із використанням моделей лонгітюдних даних. Розроблено систему економетричних ANCOVAмоделей для сільськогосподарських підприємств. Подано економічне тлумачення всіх характеристик зв'язку та показано можливості використання моделей на практииі. Значну питому вагу оборотних активів сільськогосподарських підприсмств становлять запаси, дебіторська заборгованість, поточні біологічні активи. Доведено, щзо проблема ефективного управління оборотними активами є водночас і проблемою управління прибутком.
\end{abstract}

Ключові слова: лонгітюдні дані, економетрична модель, оборотні активи, сільськогосподарське підприємство, прибуток.

Постановка проблеми. Одним із напрямів актуальних досліджень у сфері економіки підприємства $є$ пошук шляхів підвищення прибутковості суб'єкта господарювання. Поскільки основною метою діяльності будь-якого підприємства $є$ отримання максимального прибутку, як правило, у більшості випадків це відбувається за рахунок розширення своєї діяльності, збільшення обсягів продажу або підвищення ефективності використання ресурсів. Дане дослідження спрямоване на вивчення третього підходу, зокрема підвищення ефективності використання оборотних активів.

Процес управління сільськогосподарським підприємством безпосередньо пов'язаний із питаннями управління оборотними активами, так як стосується всього виробничо-фінансового циклу (постачання, виробництво, реалізація).

$\mathrm{y}$ процесі управління оборотними активами здійснюється вплив на їх величину й величину джерел їхнього утворення, суму витрат по зберіганню запасів і залученню ресурсів, необхідних для забезпечення процесу виробництва й реалізації продукції. Зміна цих параметрів впливає на кінцеві результати роботи, а отже, й на ефективність функціонування підприємства.

Аналіз останніх досліджень і публікацій, у яких започатковано розв'язання проблеми. Дослідження основних аспектів управління оборотними активами не $\epsilon$ новим, оскільки їм при- святили свої праці науковці минулого та сучасні автори. Теоретичні та практичні аспекти економічного аналізу оборотних активів знайшли висвітлення у наукових працях вітчизняних і зарубіжних економістів, зокрема Чупіса А. В., Багацької К. В., Катан Л. І. [8], Поддерьогіна А. М. [6], Чумаченка М. Г. [7] та інших.

Більшість вчених досліджували проблеми управління оборотними активами на теоретичному рівні чи то на рівні аналізу статистичної інформації. Проте вкрай важливим, на нашу думку, є аналіз відповідних тенденцій за допомогою економіко-математичного моделювання. Його вважаємо важливим інструментом системних досліджень, що дає змогу здійснити планування та прогнозування.

Мета: побудувати багатофакторну економетричну модель на основі лонгітюдних даних, визначивши сукупну дію факторів на модельований показник.

Завдання:

- структурувати оборотні активи, щоб їх ліквідність і платоспроможність підприємства перебували в рівновазі;

- побудувати економетричну модель втрат чистого прибутку залежно від суми товарної дебіторської заборгованості, запасів, поточних біологічних активів та величини оборотних активів в цілому.

Матеріали і методи досліджень. Використовувалися наступні методи дослідження: порівняння, статистичного аналізу, математичного моделювання, аналітичного прогнозування, кореляційно-регресійний аналіз.

Обробку даних здійснено за допомогою персонального комп'ютера 3 використанням пакета Excel для Windows.

Результати досліджень. Управлінський (внутрішній) аналіз оборотних активів - важливий етап у фінансовому плануванні та прогнозуванні фінансових потреб підприємства, а також ефективна інформаційна база для визначення майбутніх дій із формування і використання фінансових ресурсів.

Такий аналіз дає можливість пошуку найбільш 


\section{EKOHOMIKA}

вигідних комбінацій між прогнозованими змінними витратами на одиницю продукції, в які включаються елементи оборотних активів, постійними витратами, ціною та обсягами продажів.

На основі управлінського аналізу ефективності використання оборотних активів сільськогосподарських підприємств можна зпрогнозувати політику управління окремим елементом оборотних активів, а також виявити резерви і визначити обсяги додаткового фінансування.

Цим обумовлена об'єктивна необхідність поглибленого вивчення й дослідження аналітичних методів прогнозування та моделювання.

Необхідно структурувати оборотні активи таким чином, аби їх ліквідність і платоспроможність підприємства перебували в рівновазі, поскільки якщо грошові кошти, дебіторська заборгованість і виробничо-матеріальні запаси підтримуються на відносно низькому рівні, то ймовірність неплатоспромож-ності або нестачі засобів для забезпечення рентабельної діяльності підприємства досить велика.

Структура оборотних активів різних галузей народного господарства України наведена в таблиці. Згідно з даними таблиці, станом на 1 січня 2012 року в народному господарстві України запаси становили 24,31\%, дебіторська заборгованість - 58,04\%, у сільському господарстві, відповідно, - 46,39 та 45,29\%.

Розглядаючи структуру оборотних активів в окремих галузях народного господарства, бачимо, що в усіх галузях найбільшу питому вагу займає дебіторська заборгованість.

Для галузей iз високою матеріаломісткістю продукції характерною особливістю $є$ значна питома вага оборотних активів у запасах сировини й основних матеріалів. Це такі галузі як сільське господарство і промисловість, в яких запаси становлять 46,39 і 26,51 \% у структурі оборотних активів відповідно.

Для сільського господарства серед факторів, що впливають на структуру оборотних активів, вирішальне значення мають виробничі: питома вага виробничих запасів у досліджуваній галузі на 15-25 відсотків вища, ніж в інших галузях.

Для більш детального дослідження оборотних активів автором було проаналізовано 57 сільськогосподарських підприємств Степової природно-економічної зони України.

Значну питому вагу оборотних активів сільськогосподарських підприємств становлять запаси, дебіторська заборгованість, поточні біологічні активи.

Підприємства, що досліджуються протягом цього часу, втрачають певну суму чистого прибутку, що пов'язано зі структурою оборотних активів. Звідси, проблема в ефективному управлінні оборотними активами є одночасно й проблемою управління прибутком.

Для вирішення цих проблем у роботі пропонується застосовувати економетричне моделювання.

Побудувавши економетричну модель втрат чистого прибутку залежно від суми товарної дебіторської заборгованості, запасів, поточних біологічних активів і величини оборотних активів у цілому, можна визначити потенційні втрати чистого прибутку на перспективу.

Це означає, що сільськогосподарське підприємство може заздалегідь піклуватися про компенсацію можливих втрат прибутку, застосовуючи різні методи страхування, коригувати оборотні активи 3 метою оптимізації їх структури та оборотності.

3-поміж досліджуваних сільськогоподарських підприємств відібрали два підприємства, що отримали у 2012 році найбільший прибуток.

Розробимо систему економетричних моделей для кожного підприємства та обгрунтуємо економічне тлумачення всіх характеристик зв'язку й покажемо можливості їх використання на практиці.

Економетрична модель - це функція чи система функцій, що описує кореляційно-регресійний зв'язок між економічними показниками, один чи кілька 3 яких є залежною змінною, інші - незалежними [2]. Усі розрахунки, необхідні для побудови моделі, здійснено за допомогою Microsoft Excel. При побудові моделі використовується коваріаційний аналіз залежності коефіцієнтів.

Коваріаційний аналіз (analysis of covariance ANCOVA) - це спеціальний метод аналізу дисперсій, в якому ефекти однієї чи більше незалежних змінних, виражених у метричній шкалі, видаляють із залежної змінної перед проведенням дисперсійного аналізу.

Результатом коваріаційного аналізу є матриця, розмір якої дорівнює кількості векторів незалежних змінних, на діагоналях якої знаходяться дисперсії відповідних змінних [3].

В економічних дослідженнях найбільш широке використання знайшли моделі лінійної регреciï, хоча це і $є$ спрощений засіб у моделюванні реальних економічних процесів. Грунтовне вивчення і застосування методики побудови лінійних моделей надає необхідну теоретичну базу для створення більш складних, нелінійних моделей, які більше відповідають реальним економічним процесам [5]. 
ЕКОНОМІКА

Структура оборотних активів підприємств різних галузей народного господарства станом на 1 січня 2012 року, \%*

\begin{tabular}{|l|c|c|c|c|c|c|}
\hline \multirow{2}{*}{$\begin{array}{c}\text { Галузь народного } \\
\text { господарства }\end{array}$} & $\begin{array}{c}\text { Оборотні } \\
\text { активи, } \\
\text { разом }\end{array}$ & zапаси & $\begin{array}{c}\text { дебіторська } \\
\text { заборгованість }\end{array}$ & $\begin{array}{c}\text { поточні } \\
\text { фінансові } \\
\text { інвестиції }\end{array}$ & $\begin{array}{c}\text { грошові } \\
\text { кошти та їх } \\
\text { еквіваленти }\end{array}$ & $\begin{array}{c}\text { інші } \\
\text { оборотні } \\
\text { активи }\end{array}$ \\
\hline $\begin{array}{l}\text { Сільське господарст- } \\
\text { во, мисливство та } \\
\text { лісове господарство }\end{array}$ & 100,00 & 46,39 & 45,29 & 0,55 & 5,57 & 2,21 \\
\hline Промисловість & 100,00 & 26,51 & 63,69 & 1,83 & 5,40 & 2,57 \\
\hline Будівництво & 100,00 & 20,53 & 57,53 & 11,16 & 5,68 & 5,10 \\
\hline Торгівля & 100,00 & 20,01 & 59,56 & 10,29 & 5,46 & 4,67 \\
\hline Готелі та ресторани & 100,00 & 14,95 & 57,59 & 9,66 & 14,07 & 3,73 \\
\hline Транспорт і зв'язок & 100,00 & 19,95 & 59,85 & 2,23 & 14,69 & 3,28 \\
\hline Фінансова діяльність & 100,00 & 32,97 & 41,19 & 18,84 & 6,64 & 0,36 \\
\hline $\begin{array}{l}\text { Операції з нерухо- } \\
\text { містю }\end{array}$ & 100,00 & 18,36 & 60,24 & 11,70 & 6,18 & 3,52 \\
\hline Освіта & 100,00 & 10,70 & 50,79 & 2,71 & 32,71 & 3,09 \\
\hline Усього & 100,00 & 24,31 & 58,04 & 8,18 & 6,12 & 3,34 \\
\hline
\end{tabular}

Примітка: * - складено автором за даними Державного комітету статистики України [1]

Необхідно побудувати лінійну модель залежності приросту чистого прибутку (Y) в залежності від структури оборотних активів. Вибираємо лінійну модель:

$$
\hat{\mathrm{y}}=a_{0}+a_{1} x_{1}+a_{2} x_{2}+a_{3} x_{3}+a_{4} x_{4} \text {. }
$$

До групи сільськогосподарських підприємств, що отримали найбільший прибуток у 2012 році, серед досліджуваних підприємств, належать два підприємства: ВАТ «Петромихайлівське» Запорізької області та ПАТ «Шарівське» Кіровоградської області. Дані цих підприємств взято за вісім років (2005-2012 рр.). Таким чином, для дослідження взято 16 спостережень, що належать до лонгітюдних даних, оскільки вони сформовані за двома ознаками - просторовою та часовою [4].

На основі цих даних автором побудована економетрична модель для ВАТ «Петромихайлівське» (1) та для ПАТ «Шарівське» (2):

$\hat{y}=2517,06-0,55 X_{1}+2,48 X_{2}-0,12 X_{3}+2,39 X_{4}$

$\mathrm{R}^{2}=0,66$

$\hat{\mathrm{y}}=10383,67+0,23 \mathrm{X}_{1}-12,25 \mathrm{X}_{2}+0,89 \mathrm{X}_{3}-0,25 \mathrm{X}_{4}$

$\mathrm{R}^{2}=0,83$,

де: $\hat{y}$ - вектор втрат прибутку підприємств;

$\mathrm{X}_{1}$ - величина оборотних активів;

$\mathrm{X}_{2}$ - величина запасів;

$\mathrm{X}_{3}$ - величина поточних біологічних активів;

$\mathrm{X}_{4}$ - величина дебіторської заборгованості.

Під економетричними моделями наведений коефіцієнт детермінації $\mathrm{R}^{2}=0,66$ та $\mathrm{R}^{2}=0,83$, a це означає, що зміна втрат прибутку на $66 \%$ та на $83 \%$ залежить від зміни досліджуваних пояснювальних змінних. Мультиколінеарність відсутня: $\operatorname{det} \mathrm{r}=0,88$.

Рівняння зв'язку (1) описує залежність між втратами чистого прибутку і величиною оборотних активів, величиною запасів, величиною поточних біологічних активів та величиною дебіторської заборгованості для ВАТ «Петромихайлівське». Рівняння зв'язку (2) описує залежність втрат прибутку від величини оборотних активів, величини запасів, величини поточних біологічних активів і величини дебіторської заборгованості ВАТ «Шарівське».

Подамо економічний зміст отриманих характеристик зв'язку для ВАТ «Петромихайлівське». Зменшення величини оборотних активів на 1 тис. грн може збільшити втрати чистого прибутку на 0,55 тис. грн, збільшення величини запасів та дебіторської заборгованості призведе до втрати чистого прибутку на 2,48 та 2,39 тис. грн відповідно, а за рахунок зменшення поточних біологічних активів чистий прибуток знизиться на 0,12 тис. гривень.

Побудовані рівняння зв'язку можуть бути використані даними підприємствами для управління комерційними кредитними ризиками. Заздалегідь можна визначити можливі втрати прибут- 


\section{EKOHOMIKA}

ку через наявність певної суми дебіторської заборгованості та запасів, а це дозволить застосувати управлінські рішення для мінімізації суми втрат прибутку, оптимізації структури оборотних активів і створить (за необхідності) страховий фонд.

Висновок. У результаті проведених досліджень визначено, що раціональне розміщення (як складова управління оборотними активами) має певні особливості навіть на різних підприємствах однієї галузі. Визначальними тут $є$ певні чинники: вид господарської діяльності, обсяг виробництва; рівень технології та організації виробництва; термін виробничого циклу; система постачання необхідних товарно-матеріальних цінностей і реалізації продукції тощо. Застосовуючи економетричне моделювання за використання лонгітюдних даних кожне сільськогоспо-

\section{БІБЛІОГРАФІЯ}

1. Державний комітет статистики України: офіційний сайт [Електронний ресурс] / Статистична інформація. - Режим доступу: http://www.ukrstat.gov.ua.

2. Лешинский О. Л. Економетрія: навч. посібник / О. Л. Лещинский. - К.: МАУП, 2003. - 208 с.

3. Лугінін $О$. $Є$. Економетрія: навч. посібник 2-ге видання, перероб. та доп. / О. Є. Лугінін. К. : Центр учбової літератури, 2008. - 278 с.

4. Лук'яненко І. Г. Особливості застосування моделей лонгітюдних даних при прогнозуванні складових місцевих бюджетів / I. Г. Лук'яненко // Экономика Крыма. - №12, 2004. - С. 50-53. дарське підприємство може формувати оптимальну величину й структуру оборотних активів.

Подальші дослідження в формуванні оптимальної структури оборотних активів вимагають досягнення наступних цілей:

- перевірити на основі F-критеріїв можливість використання моделей, розрахованих на основі окремих елементів оборотних активів із фіктивними змінними, адекватно представляти структуру оборотних активів сільськогосподарського підприємства;

- побудувати на основі інформації, що містить лонгітюдні дані, сформовані на основі структурного чинника (часового періоду) математичні моделі прогнозування фінансового стану сільськогосподарського підприємства за умови ефективного використання оборотних активів.

5. Мамаева 3. М. Введение в эконометрику / 3. М. Мамаева. - Нижний Новгород : ННГУ, 2010. - $70 \mathrm{c}$.

6. Фінансовий менеджмент : Підручник / Кер. кол. авт. і наук. ред. проф. А. М. Поддєрьогін. К. : КНЕУ, 2005. - $536 \mathrm{c}$.

7. Чумаченко М. Г. Економічний аналіз : Навч. посібник / М. Г. Чумаченко, М. А. Болюх, В. 3. Бурчевський, М. І. Горбаток. - Вид. 2-ге, перероб. і доп. - К. : КНЕУ, 2003. $-556 \mathrm{c}$.

8. Чуnic A. B. Фінансова санація підприємств / А. В. Чупіс, К. В. Багацька, Катан Л. І. - Суми : Довкілля, 2006. - 326 с. 